\title{
AMMI and GGE Bi-plot Analysis for Seed Yield and Oil Content of Sesame (Sesamum indicum L.) Genotypes in Tigray, Northern Ethiopia
}

\author{
Yirga Belay Kindeya (Corresponding Author) \\ Tigray Agricultural Research Institute (TARI), Ethiopia Humera Agricultural Research Center (HuARC), Ethiopia \\ Email: yirgabelay66@gmail.com
}

\section{Firew Mekbib}

Haramaya University, College of Agriculture and Environmental Science, School of Plant Science, Department of Plant Breeding and Genetics, Dire Dawa, Ethiopia

\section{Eyasu Abraha Alle}

Tigray Agricultural Research Institute (TARI), Ethiopia Humera Agricultural Research Center (HuARC), Ethiopia

\author{
Article History \\ Received: March 16, 2020 \\ Revised: April 3, 2020 \\ Accepted: April 11, 2020 \\ Published: April 13, 2020 \\ Copyright (c) 2020 ARPG \& \\ Author \\ This work is licensed under \\ the Creative Commons \\ Attribution International \\ (9) (1) $\mathrm{CC}$ \\ BY: Creative Commons \\ Attribution License 4.0
}

\begin{abstract}
Seventeen sesame genotypes were tested at ten environments in Tigray, Northern Ethiopia during 2014-2015 cropping seasons. Randomized Complete Block Designs (RCBD) with three replications was used in the study. According to the GGE bi-plot different sesame growing environments grouped into two mega-environments: The first mega-environment contained the favorable environments Dansha area with a vertex G4 and Sheraro area with winner G3 and the second environment included medium to low environments E2 (Humera-2), E4 (Dansha-2), E5 (Sheraro-1), E7 (Wargiba-1), E8 (Wargiba-2) and E9 (Maykadra) for seed yield. Three mega-environments identified for oil content: The 1st environment contained G12, G7 and G2 in the mega-environment group of Humera, Dansha and Gendawuha, The $2^{\text {nd }}$ environment, Sheraro location contained G9 and the $3^{\text {rd }}$ environment Wargiba, was containing G17. G1 (HuRC-4) identified as an "ideal" genotype and E1 (Humera-1) also identified as an ideal environment the most representative of the overall environments and the most powerful to discriminate genotypes. The multivariate approaches AMMI and GGEbi-plot were better for partitioning the GEI into the causes of variation. According to different stability models, G1, G7, and G3 were high yielder and the most stable both in terms of seed yield and oil content. Moreover, showed yield advantages over the released and local varieties. The stable genotypes recommended for wider areas while G14 and G4 were for specific favorable environments Sheraro and Dansha, respectively.
\end{abstract}

Keywords: AMMI; ASV; GGE biplot; Oil content; Seed yield; Sesame; YSI.

\section{Introduction}

Sesame (Sesamum indicum L.) is an annual, indeterminate plant with a diploid chromosome number of $2 n=2 x=26$ and belonging to family Pedaliacea. It is a Sanjayrao Khairnar and Arjanbhai Monpara 2 plant breeder's dream crop because it presents a great genetic variability Janick and Whipkey [1]. The additive main effects and multiplicative interaction

(AMMI) method integrates analysis of variance and principal components analysis into a unified approach Gauch [2]. According to Zobel, et al. [3] it can be used to analysis METs. The AMMI method is used for three main purposes. The first is model diagnoses, AMMI is more appropriate in the initial statistical analysis of yield trials, because it provides an analytical tool of diagnosing other models as sub cases when these are better for particular data sets Gauch [2]. Secondly, AMMI clarifies the GEI and summarizes patterns and relationships of genotypes and environments Zobel, et al. [3].The third use is to improve the accuracy of yield estimates. Gains have been obtained in the accuracy of yield estimates that are equivalent to increasing the number of replicates by a factor of two to five Zobel, et al. [3].

AMMI stability value (ASV) was calculated in the excel spread sheet using the formula developed by Purchase [4]:

$$
\mathrm{ASV}=\sqrt{\left[\frac{\mathrm{SS}_{\text {IPCA1 }}}{\mathrm{SS}_{\text {IPCA2 }}}\left(\text { IPCA }_{\text {score }}\right)\right]^{2}+\left(\text { IPCA } 2_{\text {score }}\right)^{2}}
$$

Where, ASV= AMMI's stability value, $\mathrm{SS}=$ sum of squares, IPCA1=interaction of principal component analysis one, IPCA2 = interaction of principal component analysis two. Similarly Yield stability index (YSI) was also computed by summing up the ranks from ASV and mean seed yield Farshadfar, et al. [5]:

YSI $=$ RASV+RGY

Where: RASV is rank of AMMI stability value and RGY is rank of mean seed yield to statistically compare the stability analysis procedures used in the study, the Spearman's coefficient of rank correlation $\left(\mathrm{r}_{\mathrm{s}}\right)$ Steel and Torrie [6] was estimated using SPSS version 16 statistical software. 
The seed yield data were subjected to AMMI analysis, which combines analysis of variance (ANOVA) with additive and multiplicative parameters in to a single model Gauch [2]. After removing the replicate effect when combining the data, the genotypes and environments observations are partitioned in to two sources: Additive main effects for genotypes and environments; and non-additive effects due to genotype by environment interaction. A biplot showing the genotype and environmental means against IPCA1 was also performed via this model using GenStat (V16). The AMMI model is:

$$
\mathrm{Y}_{\mathrm{ij}}=\mu+\mathrm{G}_{\mathrm{i}}+\mathrm{E}_{\mathrm{j}}+\sum_{k=1}^{\mathrm{n}} \lambda_{k} \alpha_{i k} \gamma_{j k}+\theta_{i j} \text { Where: }
$$

$Y_{i j}$ is the observed mean yield of $i^{\text {th }}$ genotype in the $j^{\text {th }}$ environment; $\mu$ is the grand mean; $G_{i}$ is the $i^{\text {th }}$ genotypic effect; $\mathrm{E}_{\mathrm{j}}$ is the $\mathrm{j}^{\text {th }}$ environment effect; $\lambda_{k}$ is the eigen value of the principal component analysis (PCA) axis k; $\alpha_{i k}$ and $\gamma_{j k}$ are the $\mathrm{i}^{\text {th }}$ genotype $\mathrm{j}^{\text {th }}$ environment PCA scores for the PCA axis $\mathrm{k} ; \theta_{i j}$ is the residual; $\mathrm{n}$ is the number of PCA axes retained in the model. The number $n$ is judged on the basis of empirical consideration of F-test of significance

GGE bi-plot is a data visualization tool, which graphically displays a G x E interaction in a two way table Yan and Rajcan [7]. GGE bi-plot is an effective tool for: 1) mega-environment analysis (e.g. "which-won-where" pattern), whereby specific genotypes can be recommended to specific mega-environments Yan and Kang [8], 2) genotype evaluation (the mean performance and stability), and 3) environmental evaluation (the power to discriminate among genotypes in target environments). Sabaghnia, et al. [9] and Farshadfar, et al. [10] in wheat; Munawar, et al. [11] and Fiseha, et al. [12] in sesame are among the many authors who used GGE bi-plot to identify mega environments, to evaluate the genotypes and to test the environments.

GGE bi-plot is able to show the best genotype with the highest yield in a quadrant containing identical locations (Mega-Environments), genotype average performance and stability, ideal genotype and ideal location to increase yield and specific location. Visualization of GGE biplot is very useful to evaluate and find the most stable genotypes Farshadfar, et al. [10]. Genotypes laid in the concentric area are the most stable compared to the genotypes laid outside, even though the environmental effect was very strong Untung, et al. [13]. An ideal genotype is defined as one that is the highest yielding across test environments and absolutely stable in performance (that ranks the highest in all test environments Farshadfar, et al. [14]. Although such an "ideal" genotype may not exist in reality, it could be used as a reference for genotype evaluation Mitrovic, et al. [15]. A genotype is more desirable if it is located closer to "ideal" genotype Mitrovic, et al. [15] and Kaya, et al. [16].

\section{Materials and Methods}

The experiment was conducted in Tigray, Northern Ethiopia presented below (Table 2)

Table-1. Agro-climatic and soil types of six tested locations in Northern Ethiopia

\begin{tabular}{l|l|l|l|l|l|l}
\hline \multirow{2}{*}{ Description } & \multicolumn{2}{|l}{ Locations } & \multicolumn{3}{l}{} \\
\cline { 2 - 7 } & Dansha & Maykadra & Humera & Sheraro & Wargiba & Gendawuha \\
\hline Altitude $(\mathrm{m}$. a.s.l $)$ & 696 & 646 & 609 & 1028 & 1578 & 760 \\
\hline Latitude $\left({ }^{\circ} \mathrm{N}\right)$ & $13^{\circ} 36^{\prime}$ & $14^{\circ} 02^{\prime}$ & $14^{\circ} 15^{\prime}$ & $14^{\circ} 24^{\prime}$ & $12^{\circ} 41^{\prime}$ & $12^{\circ}$ \\
\hline Longitude $\left({ }^{\circ} \mathrm{E}\right)$ & $36^{\circ} 41^{\prime}$ & $36^{\circ} 35^{\prime}$ & $36^{\circ} 37^{\prime}$ & $37^{\circ} 45^{\prime}$ & $39^{\circ} 42^{\prime}$ & $36^{\circ}$ \\
\hline R.F. $(\mathrm{mm})$ & 888.4 & $\mathrm{NA}$ & 576.4 & 1000 & 750 & $850-1100$ \\
\hline Temp. $\left({ }^{\circ} \mathrm{C}\right)$ & 28 & NA & $18.8-37.6$ & $18.8-34.9$ & $18-25$ & $19.5-35.7$ \\
\hline Soil type & Vertisol & $\begin{array}{l}\text { Chromic } \\
\text { vertisol }\end{array}$ & $\begin{array}{l}\text { Chromic } \\
\text { Vertisol }\end{array}$ & Vertisols & NA & Vertisol \\
\hline
\end{tabular}

Source: Bereket. and Yirgalem [17] Meteorology data (Dansha, Humera, and Maykadra): IPMS-ETHIOPIA [18] (for Gendawuha), NA=Not Available

Table-2. The Study locations in Northern Ethiopia in 2014-2015 cropping season

\begin{tabular}{l|l|l|l}
\hline Location & District & Year & $\mathbf{2 0 1 5}$ \\
\cline { 3 - 4 } & & $\mathbf{2 0 1 4}$ & E2 \\
\hline Humera & K/Humera & E1 & E4 \\
\hline Dansha & Tsegede & E3 & E6 \\
\hline Sheraro & T/Adyiabo & E5 & E8 \\
\hline Wargiba & R/Azebo & E7 & E9 \\
\hline Maykadra & K/Humera & - & E10 \\
\hline Gendawuha & Metema & - & \multicolumn{2}{l}{ E2 }
\end{tabular}

Note: K/Humera=Kafta Humera, T/Adyiabo=Tahtay Adyiabo, R/Azebo=Raya Azebo. E1=Humera, E2=Humera-2, E3=Dansha-1, E4=Dansha-2, E5=Sheraro-1, E6=Sheraro-2, E7=Wargiba-1, E8=Wargiba-2, E9=Maykadra, E10=Gendawuha

\subsection{Experimental Genotypes}

Seventeen sesame planting materials were used in the study presented (Table 3). 
Journal of Agriculture and Crops

Table-3. Description of genotypes used in the study

\begin{tabular}{|c|c|c|c|}
\hline Genotype (G) & Code & Status & Sources \\
\hline HuRC-4 & G1 & Advance line & HuARC \\
\hline Acc202514 & G 2 & Advance line & HuARC \\
\hline Land race Gumero & G 3 & Advance line & HuARC \\
\hline Abuseffa & G 4 & Advance line & HuARC \\
\hline HuRC-1 & G 5 & Advance line & HuARC \\
\hline Rawyan -2 & G 6 & Advance line & HuARC \\
\hline HuRC-3 & G 7 & Advance line & HuARC \\
\hline Acc 202300 & G 8 & Advance line & HuARC \\
\hline Kefif & G9 9 & Advance line & HuARC \\
\hline Acc111824 & G 10 & Advance line & HuARC \\
\hline Acc 111518 & G 11 & Advance line & HuARC \\
\hline Acc 27913 & G 12 & Advance line & HuARC \\
\hline Gumero & G 13 & Advance line & HuARC \\
\hline HuRC-2 & G 14 & Advance line & HuARC \\
\hline Acc 227880 & G 15 & Advance line & HuARC \\
\hline Setit -1(Standard check) & G 16 & Released & HuARC \\
\hline Hirhir (Local check) & G 17 & Local & HuARC \\
\hline
\end{tabular}

Source: Humera Agricultural Research Center [19] Annual report

\subsection{Experimental Design and Management}

The experiment was laid out in randomized complete block design (RCBD) with three replications. Each genotype was randomly assigned and sown in a plot area of $2 \mathrm{~m} \times 5 \mathrm{~m}$ with $1 \mathrm{~m}$ between plots and $1.5 \mathrm{~m}$ between blocks keeping inter and intra row spacing of $40 \mathrm{~cm}$ and $10 \mathrm{~cm}$, respectively.

\subsection{Data Analysis}

Analysis of variance for each environment, combined analysis of variance over environments and AMMI analysis were computed using GenStat statistical softwre $16^{\text {th }}$ edition GenStat [20]. Unbalanced design was used for combined analysis of variance because of different locations and years in the study. The model employed in the analysis was;

$$
\text { Yijk }=\mu+\mathrm{Gi}+\mathrm{Ej}+\mathrm{Bk}+\mathrm{GEij}+\text { eijk where: }
$$

Yijk is the observed mean of the $\mathrm{i}^{\text {th }}$ genotype $(\mathrm{Gi})$ in the $\mathrm{j}^{\text {th }}$ environment $(\mathrm{Ej})$, in the $\mathrm{k}^{\text {th }}$ block $(\mathrm{Bk})$; $\mu$ is the overall mean; $\mathrm{Gi}$ is effect of the $\mathrm{i}^{\text {th }}$ genotype; $\mathrm{Ej}$ is effect of the $\mathrm{j}^{\text {th }}$ environment; $\mathrm{Bk}$ is block effect of the $\mathrm{i}^{\text {th }}$ genotype in the $\mathrm{j}^{\text {th }}$ environment; GEij is the interaction effects of the $\mathrm{i}^{\text {th }}$ genotype and the $\mathrm{j}^{\text {th }}$ environment; and cijk is the error term.

\section{Result and Discussion}

\subsection{Mean of Genotypes for Seed Yield and Oil Content Across Ten Environments}

The mean seed yield of the environments in 2014-2015 and oil content during 2015 main seasons was highly significant at $(\mathrm{p} \leq 0.001)$. Overall mean seed yield over ten environments was $649.35 \mathrm{~kg} / \mathrm{ha}$ and the mean seed yield of genotypes across environments ranged between $238.5 \mathrm{~kg} / \mathrm{ha}$ in E2 to $1123.8 \mathrm{~kg} / \mathrm{ha}$ in E3. Among high yielded genotypes, G1, G7, and G3 showed $18.85 \%, 7.30 \%$ and $1.34 \%$ yield advantage over the recently released and $34.25 \%, 22.75 \%$ and $16.75 \%$ over the local varieties, respectively. Changing sesame yield performance with environments reported by Fiseha, et al. [12], Mekonnen, et al. [21] and Mohammed [22] in sesame.

The grand mean oil content of the genotypes over six environments were $49.9 \%$ and the mean oil content ranged between $49 \%$ in G5 to $51.9 \%$ in G12 across the tested locations this result in line with the major requirements for sesame export are pearly white seed color and 40-50\% oil content. The oil content percentage was varied among genotypes and is consistent with the previous findings: Zenebe and Hussien [23] 45.9-52-5\% 24-58\%, Alege and Musapha [24] 38-57\% Yahaya, et al. [25], 45.2-52.7\% Mohammed [22] and 46.4\%-53.4\% Mekonnen, et al. [21]. Gendawuha $(52.5 \%)$ gave the highest mean oil content followed by Sheraro $(50.99 \%$ and Dansha $(50.6 \%)$ which received optimum rainfall in the 2015 main cropping season resulted in high oil content while Humera (48.2\%), Wargiba (48.5\%) and Maykadra (48.61\%). Oil content greatly across seasons and environments among genotypes. This result is in agreement with Zenebe and Hussien [23] and Mekonnen, et al. [21]. To improve the oil content of sesame genotypes, selection should be based on high seed yield with relatively high oil content or cross-breeding of high seed yielded with high oil content genotypes. 
Table-4. Mean yield (kg/ha) of 17 genotypes across 10 environments in 2014-2015 main season

\begin{tabular}{|c|c|c|c|c|c|c|c|c|c|c|c|}
\hline \multicolumn{12}{|c|}{ Environments } \\
\hline $\mathrm{G}$ & E1 & E2 & E3 & E4 & E5 & E6 & E7 & E8 & E9 & E10 & Mean \\
\hline G1 & $1107.6^{\mathrm{a}}$ & $361.7^{\mathrm{ab}}$ & $1173^{\text {bed }}$ & $670.5^{\mathrm{ab}}$ & $619.8^{\text {bcd }}$ & $1325^{\mathrm{a}}$ & $844.2^{\mathrm{a}}$ & $756^{\mathrm{a}}$ & $761.7^{\mathrm{a}}$ & $1054.9^{\mathrm{sb}}$ & $867.4^{\mathrm{a}}$ \\
\hline G2 & $967.7^{\mathrm{bc}}$ & $222.5^{\text {cd }}$ & $1065^{\text {def }}$ & $671.8^{\mathrm{ab}}$ & $341.7^{\text {gh }}$ & $974^{\text {ef }}$ & $385.8^{\mathrm{de}}$ & $203.7^{\mathrm{g}}$ & $238.9^{\mathrm{h}}$ & $761.1^{\mathrm{bc}}$ & $583.3^{\mathrm{hi}}$ \\
\hline G3 & $1070.9^{\mathrm{ab}}$ & $347.8^{b}$ & $1467^{\mathrm{a}}$ & $453.5^{\text {cde }}$ & $866.1^{\mathrm{a}}$ & $1056^{\text {de }}$ & $675.9^{\mathrm{ab}}$ & $378.3^{\text {de }}$ & $446.1^{\mathrm{d}}$ & $776.4^{\mathrm{bc}}$ & $753.8^{\mathrm{bc}}$ \\
\hline $\mathrm{G} 4$ & $849.1^{\text {cdeff }}$ & $227.2^{\mathrm{cd}}$ & $1258^{b}$ & $763.9^{\mathrm{a}}$ & $584^{\text {bcde }}$ & $1329^{\mathrm{a}}$ & $542.3^{\text {bcd }}$ & $366.3^{\text {de }}$ & $321.9^{f}$ & $445.2^{\mathrm{d}}$ & $668.6^{\text {ef }}$ \\
\hline G5 & $677.5^{\mathrm{ij}}$ & $233.3^{\text {cd }}$ & $957^{f}$ & $533.3^{\text {bcd }}$ & $716.7^{b}$ & $1183^{\mathrm{bc}}$ & $655.9^{b}$ & $714.3^{\mathrm{a}}$ & $512.2^{c}$ & $762.6^{b c}$ & $694.6^{d a}$ \\
\hline G6 & $983.6^{b}$ & $237.5^{c}$ & $1125^{\text {cd }}$ & $338.6^{\mathrm{e}}$ & $322.4^{h}$ & $853^{\mathrm{fghi}}$ & $461.2^{\text {cds }}$ & $481.7^{\text {cd }}$ & $345.3^{\mathrm{f}}$ & $828.8^{\mathrm{bc}}$ & $597.7 \mathrm{ghi}$ \\
\hline G7 & $837.7^{\text {defgh }}$ & $354.7^{b}$ & $1486^{\mathrm{a}}$ & $480.2^{\text {cde }}$ & $623.8^{\text {bcd }}$ & $1158^{\text {bcd }}$ & $686.4^{\mathrm{ab}}$ & $657.7^{\mathrm{ab}}$ & $654.2^{b}$ & $986.4^{\text {ab }}$ & $792.5^{b}$ \\
\hline G8 & $611^{\mathrm{ji}}$ & $110.6^{\mathrm{e}}$ & $492^{\mathrm{g}}$ & $354.4^{\mathrm{e}}$ & $536.7^{\text {cde }}$ & $733^{\mathrm{ik}}$ & $469.9^{\text {cde }}$ & $288.3^{\text {efg }}$ & $177.9^{j}$ & $643.7^{\text {cd }}$ & $441.8^{j}$ \\
\hline G9 & $849.2^{\text {cdef }}$ & $150^{\mathrm{da}}$ & $1094^{\mathrm{de}}$ & $354.9^{2}$ & $396.7^{\mathrm{fghh}}$ & $882^{\mathrm{fghh}}$ & $363.9^{\mathrm{de}}$ & $475^{\text {cd }}$ & $4055^{8 i}$ & $846.5^{\mathrm{abc}}$ & $562.1^{\mathrm{i}}$ \\
\hline G10 & $632.1^{\mathrm{ijk}}$ & $160^{\text {cds }}$ & $1075^{\mathrm{d} s}$ & $550.3^{\mathrm{bc}}$ & $366.5^{\mathrm{gh}}$ & $855^{\mathrm{fghhi}}$ & $364.9^{\mathrm{de}}$ & $236.7^{\mathrm{fg}}$ & $208.9^{\mathrm{a}}$ & $834.5^{\mathrm{bc}}$ & $548.1^{\mathrm{i}}$ \\
\hline G11 & $681.7^{\mathrm{ij}}$ & $125^{\mathrm{e}}$ & $1132^{\text {cd }}$ & $385.4^{\mathrm{da}}$ & $550.6^{\text {cds }}$ & $1106^{\text {cd }}$ & $334.4^{\mathrm{e}}$ & $309^{\text {efg }}$ & $218.9^{\mathrm{hi}}$ & $770.2^{\mathrm{bc}}$ & $561.3^{\mathrm{i}}$ \\
\hline G12 & $729.3^{\text {ftij }}$ & $242.8^{c}$ & $1086^{d s}$ & $764.3^{\mathrm{a}}$ & $472.2^{\text {efg }}$ & $761^{\text {hjik }}$ & $393 d^{2}$ & $387.7^{\mathrm{de}}$ & $325^{f}$ & $1029.8^{\mathrm{ab}}$ & $619.1^{\text {fgh }}$ \\
\hline G13 & $853.7^{\text {cde }}$ & $170^{\text {cde }}$ & $1105^{\mathrm{d}}$ & $515.4^{\text {cd }}$ & $343.4^{\mathrm{gh}}$ & $934^{\mathrm{fg}}$ & $302.7^{e}$ & $293^{\mathrm{de}}$ & $337.2^{f}$ & $863^{\mathrm{abc}}$ & $571.8^{\mathrm{hi}}$ \\
\hline G14 & $858.9^{\text {cde }}$ & $435^{\mathrm{a}}$ & $1125^{\text {cd }}$ & $467.7^{\text {cde }}$ & $504.1^{\text {def }}$ & $1250^{\mathrm{sb}}$ & $638.5^{\mathrm{bc}}$ & $757.3^{\mathrm{a}}$ & $265.8^{g}$ & $933.6^{\mathrm{abc}}$ & $723.6^{\text {cd }}$ \\
\hline G15 & $742.8^{\text {efghhi }}$ & $233.9^{\mathrm{cd}}$ & $987^{\text {fe }}$ & $558^{\mathrm{bc}}$ & $660.6^{\mathrm{bc}}$ & $850^{\mathrm{ghhj}}$ & $425.2^{\mathrm{de}}$ & $348.3^{\text {def }}$ & $778.6^{\mathrm{a}}$ & $1043.8^{\mathrm{ab}}$ & $662.9^{\text {ef }}$ \\
\hline G16 & $868.5^{\text {cd }}$ & $218.9^{\text {cd }}$ & $1246^{b}$ & $522.6^{\text {cd }}$ & $663.5^{\mathrm{bc}}$ & $1266^{\mathrm{ab}}$ & $705.5^{\mathrm{ab}}$ & $392^{\text {de }}$ & $426.9^{\mathrm{de}}$ & $1141 \cdot 4^{\mathrm{a}}$ & $745.1^{\mathrm{bc}}$ \\
\hline G17 & $545.9^{\mathrm{k}}$ & $223.9^{\text {cd }}$ & $1232^{\mathrm{bc}}$ & $357.6^{\circ}$ & $605.6^{\text {bcde }}$ & $1203^{b c}$ & $530.3^{\text {bcd }}$ & $547^{\mathrm{bc}}$ & $449.2^{\mathrm{d}}$ & $760.1^{\mathrm{bc}}$ & $645.5^{\text {efg }}$ \\
\hline Mean & 815.7 & 238.5 & 1123.8 & 514.3 & 539.7 & 1042.24 & 516.5 & 446.60 & 404.38 & 851.9 & 649.35 \\
\hline CV\% & 8 & 18.7 & 5.6 & 15.2 & 13.3 & 6.4 & 19 & 16.2 & 3.8 & 18.3 & 13.8 \\
\hline
\end{tabular}

G=Genotypes; G1= HuARC-4(Setit-3)(Setit-3)(Setit-3), G2= Acc202514, G3= Land race Gumero, G4= Abuseffa, G5= HuRC-1, G6= Rawyan 2, G7= HuARC-3, G8= Acc 202300, G9= Kefif, G10= Acc111824, G11= Acc 111518, G12= Acc 27913, G13= Gumero, G14= HuRC-2, G15= Acc 227880, G16= Setit -1, G17= Hirhir. E1=Humera-1, E2=Humera-2, E3=Dansha-1, E4=, Dansha-2, E5=Sheraro-1, E6=Sheraro-2, E7= Wargiba-1, E8= Wargiba-2, E9=Maykadra and E10= Gendawuha

Table-5. Mean oil content (\%) of 17 genotypes across six locations during 2015 main season

\begin{tabular}{|c|c|c|c|c|c|c|c|}
\hline \multirow[b]{2}{*}{$\mathbf{G}$} & \multicolumn{6}{|c|}{ Environments } & \multirow[b]{2}{*}{ Mean } \\
\hline & E2 & E4 & E6 & E8 & E9 & E10 & \\
\hline G1 & $47.18^{\mathrm{d}}$ & $50.91^{\mathrm{bcd}}$ & $50.49^{\text {ab }}$ & 48.2 & $47.7^{\text {efg }}$ & $51.83^{\text {bcde }}$ & $50^{\text {fgh }}$ \\
\hline $\mathrm{G} 2$ & $48.52^{\mathrm{abcd}}$ & $50.27^{\text {cdef }}$ & $50.77^{\mathrm{ab}}$ & 48.37 & $49.54^{b c}$ & $53.74^{\text {ab }}$ & $50.2^{\text {abcdef }}$ \\
\hline G3 & $48.87^{\mathrm{ab}}$ & $52.03^{\mathrm{ab}}$ & $49.18^{b}$ & 48.08 & $49.78^{b}$ & $52.64^{\text {abcd }}$ & $50.10^{\text {bcdef }}$ \\
\hline G4 & $48.5^{\mathrm{abcd}}$ & $51.36^{\mathrm{abc}}$ & $50.51^{\text {ab }}$ & 48.74 & $50.27^{\mathrm{ab}}$ & $52.16^{\text {bcde }}$ & $50.26^{\text {abcde }}$ \\
\hline G5 & $47.34^{\mathrm{d}}$ & $49.58^{\mathrm{ef}}$ & $50.31^{\text {ab }}$ & 47.92 & $47.63^{\text {efg }}$ & $51.37^{\mathrm{de}}$ & $49.03^{\mathrm{h}}$ \\
\hline G6 & $47.19^{d}$ & $49.82^{\text {def }}$ & $52.09^{\mathrm{ab}}$ & 48.67 & $46.9^{\mathrm{fg}}$ & $50.49^{e}$ & $49.18^{\text {gh }}$ \\
\hline G7 & $47.67^{\text {bdd }}$ & $51.21^{b c}$ & $51.81^{\text {ab }}$ & 49.59 & $49.5^{b c}$ & $52.33^{\text {abcde }}$ & $50.35^{\text {abcd }}$ \\
\hline G8 & $48.8^{\mathrm{abc}}$ & $49.34^{\mathrm{f}}$ & $51.26^{\text {ab }}$ & 48.63 & $47.54^{\text {efg }}$ & $51.42^{\text {cde }}$ & $49.54^{\text {detgh }}$ \\
\hline G9 & $49.33^{\mathrm{a}}$ & $49.28^{f}$ & $52.62^{\mathrm{a}}$ & 48.13 & $46.79^{\mathrm{g}}$ & $51.87^{\text {bcde }}$ & $49.67^{\text {cdefgh }}$ \\
\hline G10 & $49^{\mathrm{ab}}$ & $50.7_{\text {cde }}$ & $49.91^{\text {ab }}$ & 48 & $47.63^{\text {efg }}$ & $52.17^{\text {bcde }}$ & $49.57^{\text {defgh }}$ \\
\hline G11 & $48.13^{\mathrm{abcd}}$ & $49.47^{\mathrm{ef}}$ & $50.2^{\mathrm{ab}}$ & 48.59 & $47.82^{\text {def }}$ & $52.58^{\text {abcde }}$ & $49.46^{\text {efgh }}$ \\
\hline G12 & $48.93^{\mathrm{ab}}$ & $52.52^{\mathrm{a}}$ & $51.7^{\mathrm{ab}}$ & 47.68 & $50.79^{\mathrm{a}}$ & $54.24^{\mathrm{a}}$ & $51^{\mathrm{a}}$ \\
\hline G13 & $47.32^{\mathrm{d}}$ & $50.46^{\text {cdef }}$ & $51.78^{\text {ab }}$ & 48.43 & $47.53^{\mathrm{efg}}$ & $52.3^{\text {abcde }}$ & $49.67^{\text {cdefgh }}$ \\
\hline G14 & $48.32^{\mathrm{abcd}}$ & $51.33^{\mathrm{abc}}$ & $52.03^{\text {ab }}$ & 48.29 & $49.79^{b}$ & $53.68^{\mathrm{ab}}$ & $50.6^{\mathrm{ab}}$ \\
\hline G15 & $48.4^{\mathrm{abcd}}$ & $51.29^{\mathrm{abc}}$ & $50.11^{\text {ab }}$ & 49.1 & $50.11^{\mathrm{ab}}$ & $53.39^{a b c}$ & $50.4^{\mathrm{abc}}$ \\
\hline G16 & $48.56^{\mathrm{abcd}}$ & $50.92^{\text {bcd }}$ & $51.43^{\text {ab }}$ & 48.47 & $48.26^{\mathrm{de}}$ & $54.17^{\mathrm{a}}$ & $50.3^{\text {abcd }}$ \\
\hline G17 & $47.42^{\mathrm{cd}}$ & $50.2^{\text {cdef }}$ & $50.7^{\mathrm{ab}}$ & 49.87 & $48.73^{\mathrm{cd}}$ & $52.77^{\mathrm{abcd}}$ & $49.95^{\text {bcdefg }}$ \\
\hline Mean & 48.20 & 50.6 & 50.99 & 48.5 & 48.61 & 52.5 & 49.9 \\
\hline CV\% & 1.5 & 1.3 & 3.1 & 2.8 & 1.1 & 1.9 & 1.95 \\
\hline
\end{tabular}

Values connected with the same letters in a column were not significantly different; G=Genotype, CV\%= Coefficient of variability, E2= $($ Humera-2 $), \mathrm{E} 4=($ Dansha-2 $), \mathrm{E} 6=($ Sheraro-2 $), \mathrm{E} 8=($ Wargiba-2 $), \mathrm{E} 9=($ Maykadra $), \mathrm{E} 10=($ Gendawuha $)$

\subsection{Overall Ranking of Genotypes Using Various Stability Models}

G1, G7 and G3 including the released variety (G16) and local (G17) were found the most stable and ranked $1^{\text {st }}$, $2^{\text {nd }}, 3^{\text {rd }}, 4^{\text {th }}$ and $9^{\text {th }}$. While, G4, G8 and G15 were unstable and $7^{\text {th }}, 17^{\text {th }}$ and $8^{\text {th }}$ for seed yield, respectively (Table 6). According to those models, the oil content was also varied from one environment to another. G2, G15 and G16 were the most stable and ranked $6^{\text {th }}, 3^{\text {rd }}$ and $4^{\text {th }}$. On contrary, G6, G10 and G9 were the most unstable and ranked $16^{\text {th }}, 14$ th and $13^{\text {th }}$ formean oil content across the tested locations, respectively (Table 6). 
Table-6. Ranking of seed yield of sesame genotypes based on the various stability parameters

\begin{tabular}{l|l|l|l|l|l|l|l|l|l|l|l|l|l|l|l}
\hline Stability analysis result & \multicolumn{10}{l}{ (1) } \\
\hline G & SY & R & YSI & R & ASV & R & Wi & R & Pi & R & bi & R & S di & R & OR. \\
\hline G1 & 867.4 & 1 & 6 & 2 & 5.8 & 5 & 110047 & 5 & 9036 & 1 & 0.76 & 6 & 14783.5 & 10 & 1 \\
\hline G2 & 583.3 & 12 & 23 & 8 & 11.7 & 11 & 163463 & 10 & 80169 & 13 & 1.24 & 16 & 5354.35 & 4 & 15 \\
\hline G3 & 753.8 & 3 & 13 & 3 & 10 & 10 & 233791 & 14 & 29813 & 4 & 0.89 & 5 & 20758.7 & 14 & 5 \\
\hline G4 & 668.6 & 7 & 24 & 9 & 17.1 & 17 & 341095 & 17 & 58946 & 9 & 1.11 & 12 & 4391.77 & 2 & 16 \\
\hline G5 & 694.6 & 6 & 21 & 6 & 14.8 & 15 & 188863 & 12 & 42711 & 6 & 1.09 & 11 & 10382.5 & 7 & 13 \\
\hline G6 & 597.7 & 11 & 15 & 4 & 4.9 & 4 & 123724 & 8 & 69822 & 11 & 1.13 & 13 & 37759.3 & 17 & 10 \\
\hline G7 & 792.5 & 2 & 5 & 1 & 3.8 & 3 & 115774 & 7 & 16102 & 2 & 1.08 & 9 & 4500.33 & 3 & 3 \\
\hline G8 & 441.8 & 17 & 30 & 10 & 13 & 13 & 269022 & 15 & 146926 & 17 & 0.97 & 3 & 5791.59 & 5 & 17 \\
\hline G9 & 562.1 & 14 & 16 & 5 & 2.9 & 2 & 67623 & 2 & 80574 & 15 & 1.2 & 15 & 1419.28 & 1 & 11 \\
\hline G10 & 548.1 & 16 & 23 & 8 & 7.5 & 7 & 73381 & 4 & 86227 & 16 & 0.93 & 4 & 10043.9 & 6 & 9 \\
\hline G11 & 561.3 & 15 & 21 & 6 & 6.2 & 6 & 67254 & 1 & 80386 & 14 & 1.13 & 13 & 24115.9 & 16 & 12 \\
\hline G12 & 619.1 & 10 & 24 & 9 & 14 & 14 & 202390 & 13 & 68775 & 10 & 0.57 & 17 & 12680.7 & 9 & 8 \\
\hline G13 & 571.8 & 13 & 22 & 7 & 8.9 & 9 & 70485 & 3 & 77593 & 12 & 1.05 & 8 & 16486.7 & 12 & 7 \\
\hline G14 & 723.6 & 5 & 13 & 3 & 8.3 & 8 & 169296 & 11 & 38301 & 5 & 1.09 & 10 & 16406.8 & 11 & 6 \\
\hline G15 & 662.9 & 8 & 24 & 9 & 16.4 & 16 & 270511 & 16 & 54425 & 8 & 1.02 & 1 & 12142.4 & 8 & 14 \\
\hline G16 & 745.1 & 4 & 5 & 1 & 0.8 & 1 & 114803 & 6 & 27076 & 3 & 0.99 & 2 & 17843.7 & 13 & 2 \\
\hline G17 & 645.5 & 9 & 21 & 6 & 12 & 12 & 160177 & 9 & 53505 & 7 & 0.75 & 7 & 24593.3 & 15 & 4 \\
\hline
\end{tabular}

Note: ASV=AMMI stability value, YSI=yield stability index, bi = Eberhart and Russell [26] regression coefficient, R= Rank,OR. = Overall rank, $\mathrm{Pi}=$ Lin and Binns [27] cultivar performance measure, $\mathrm{S}^{2} \mathrm{di}=$ Eberhart and Russell [26] deviation from

Regression, $\mathrm{SY}=$ Seed yield (kg/ ha) and Wi = Wricke [28] Ecovalenc.

AMMI analysis of variance of ten environments for seed yield and six locations were presented in (7). Showed highly significance variation at $(\mathrm{P} \leq 0.001)$ among genotypes, environments and GEI for seed yield and oil content. From the total variation, $69.73 \%, 14.68 \%, 9.58 \%$ were explained by environments, GEI and genotypes for seed yield and $61.6 \%, 13.64 \%$ ) and $6.55 \%$ ) for oil content, respectively. The result is agreed with the previous findings Mohammed, et al. [29] and Mekonnen, et al. [21] in sesame. This showed that the significances influence of environments on yield and oil content performance of sesame genotypes in different locations of northern Ethiopia indicating the need to test sesame genotypes under various environments. The four IPCAs were highly significant leading to a cumulative $99.8 \%$ variation and the rest $2.62 \%$ was contributed due to noise for seed yield and three IPCs significance leading to a cumulative contribution of $83.7 \%$ variation and the rest due to noise for oil content. AMMI with only the two interaction principal component axes was the best predicative model for both seed yield and oil content. This is in harmony with Zobel, et al. [3].

Table-7. AMMI's ANOVA for seed yield (kg/ha) of 17 genotypes during 2014-2015

\begin{tabular}{l|l|l|l|l|l|l}
\hline Source of variation & df. & SS. & MS. & \multicolumn{3}{l}{ Sum of squares \% explained } \\
\cline { 5 - 7 } & & & & Total V.E & GEIE & GEI Cmu. \\
\hline Genotypes & 16 & 5367408 & $335463^{* *}$ & 9.58 & & \\
\hline Environments & 9 & 39066091 & $4340677^{* *}$ & 69.73 & & \\
\hline Block within Envir. & 20 & 1306032 & $65302^{* *}$ & 2.33 & & \\
\hline Interactions & 144 & 8225103 & $57119^{* *}$ & 14.68 & & \\
\hline IPCA 1 & 24 & 4234567 & $87589^{* *}$ & & 51.56 & 51.48 \\
\hline IPCA 2 & 22 & 1849997 & $84091^{* *}$ & & 22.49 & 73.97 \\
\hline IPCA 3 & 20 & 1250159 & $62508^{* *}$ & & 15.2 & 89.17 \\
\hline IPCA 4 & 18 & 1121227 & $62290^{* *}$ & & 10.63 & 99.8 \\
\hline Residuals & 8 & 78316 & $4789^{\text {ns }}$ & & & \\
\hline Total & 281 & 62498900 & 5099828 & & & \\
\hline
\end{tabular}

** Significance at $(\mathrm{p} \leq 0.001)$ respectively. Block =replication within environments. Total V.E. $=$ Total variation explained, GEIE. $=\mathrm{GEI}$ explained and GEI cum. = GEI cumulative, $\mathrm{SS}=$ Sums of squares and MS=Means of squares

G15, G1, G16, G3, G4, G5, G14, G17 and G7 recorded seed yield above grand mean in the favorable environments, while eight genotypes G12, G8, G10, G2, G13, G6, G9 and G11 were below the grand mean and low yield in the unfavorable environments (Figure 1). Stable genotypes were adaptive to wider areas and give consistency mean yield across the test locations. G1, G7, G2, G3, G6, G9 and G16 were found nearly closer to the origin and the most stable with little responsive to the GEI. Genotypes far from the origin are sensitive to environmental changes. Hence, G4, G10, G8, G11, G12, G13, G17, G15 and G14 were the unstable. In contrast, G1, G7, G 16 and G3 were the most stable in the favorable environments. G8 and G11 were unstable with low yield in the unfavorable environments. Therefore, genotypes with high yield and wider stability performance are the most desirable for wider area.

Environments suitable to sesame production are classified according their position found in the quadrant (Figure 1). Environments on $1^{\text {st }}$ and $2^{\text {nd }}$ quadrant, E1, E3, E6, and E10 were favorable. Whereas, E9, E4, E2, E5, E8 and E7 in $3^{\text {rd }}$ and $4^{\text {th }}$ quadrant of the graph were considered as unfavorable environments. 


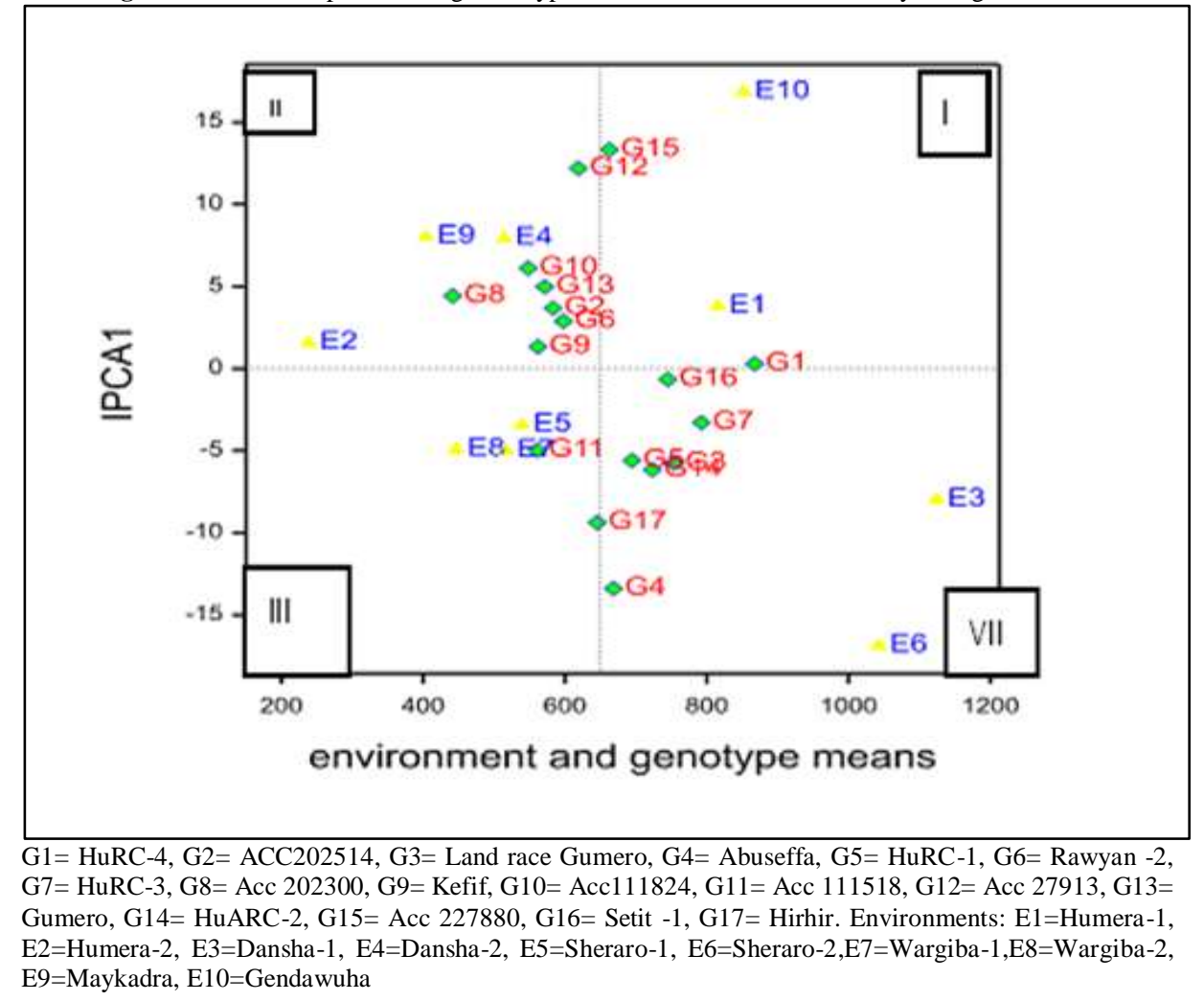

E10, E4 and E6 were favorable environments, while E2, E9 and E8 were unfavorable environments for mean oil content. Due to environmental factors the oil content varied among genotypes. Hence, G1, G5, G6, G8, G9, G10, G11 and G3 had low mean oil content in the unfavorable environments and G1, G5, G10 and G11 were the most stable found close to the origin. Whereas, G2, G4, G7, G12, G13, G14, G15, G16 and G17 were in the favorable environments and G17, G16, G7 and G14 were the most stable. Hence, improving the oil content selection should be based on high seed yield with relatively high oil content genotypes or cross breeding of high seed yielder with high oil content genotype. This is in harmony with the result of Mekonnen, et al. [21] in sesame.

Figure-2. AMMI1 showing Genotype and Environment means for oil content (\%) in 2015

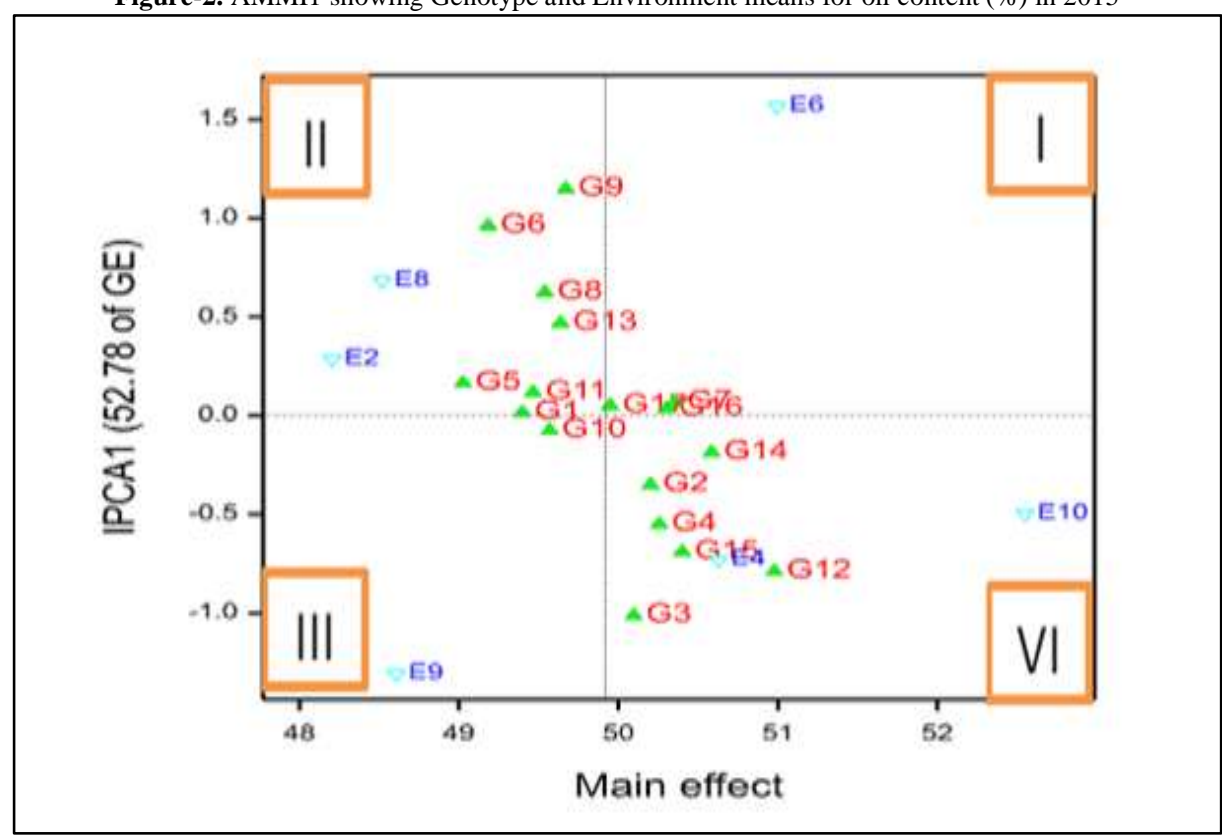

G1= HuRC-4, G2= ACC202514, G3= Land race Gumero, G4= Abuseffa, G5= HuRC-1, G6= Rawyan -2, G7= HuRC-3, G8= Acc 202300, G9= Kefif, G10= Acc111824, G11= Acc 111518, G12= Acc 27913, G13= Gumero, G14= HuARC-2, G15= Acc 227880, G16= Setit -1 , G17= Hirhir. E2=humera-2, E4=Dansha-2, E6=Sheraro-2, E8=Wargiba-2, E9=Maykadra, E10=Gendawuha

GGE bi-plot was determined using GenStat software version 16 for both seed yield and oil content. From this study G1 (HuRc-4) was the "ideal" genotype, the highest mean seed yield and the most stable across variable environments. Genotypes closer to the ideal genotype were the stable ones, while genotypes far from the ideal genotypes were unstable. A genotype is more desirable if it is located closer to the ideal genotype. A similar 
result was reported by Kaya, et al. [16]; Mitrovic, et al. [15]; Farshadfar, et al. [14]. G7, G3, G5, G16, G17 and G14 were plotted to the ideal genotype considered as desirable genotypes, while G15 and G4 were high yielding genotypes associated with genotypic instability (Figure 3). E1( Humera -1) had the longest vector with small IPCA, which fell into the center of concentric circles was considered as an ideal environment in terms of being the most representative of the overall environments and the most powerful to discriminate genotypes. The concentric circles on the bi-plot help to visualize the length of the environment vectors, which are proportional to the standard deviation within the respective environments and is a measure of the discriminating ability of the environments Asnake, et al. [30]. An environment is more desirable and discriminating when located closer to the center circle or to an ideal environment Naroui, et al. [31]. E2, E4, E5, E7 and E8 were closer to the ideal environment. E3, E10, E6, E4 and E9 were far from the ideal environment and considered as unstable (Figure 4). This result was in line with Yan, et al. [32] and Fiseha, et al. [12] presented in (Figure 3).

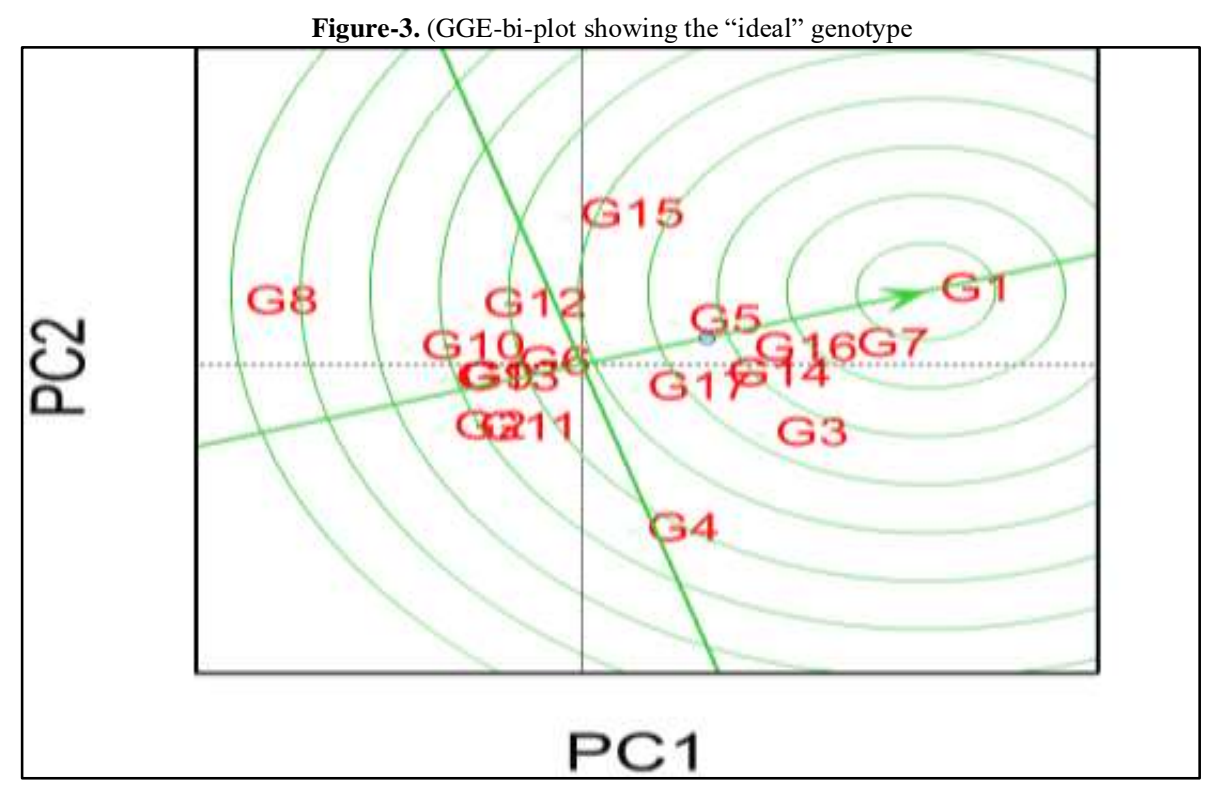

G1= HuRC-4, G2= ACC202514, G3= Land race Gumero, G4= Abuseffa, G5= HuRC-1, G6= Rawyan -2 , G7 = HuRC-3, G8= Acc 202300, G9= Kefif, G10= Acc111824, G11= Acc111518, G12= Acc 27913, G13= Gumero, G14= HuARC-2, G15= Acc 227880, G16= Setit -1 , G17= Hirhir

Figure-4. GGE-bi-plot based on the ranking of environments relative to an ideal environment

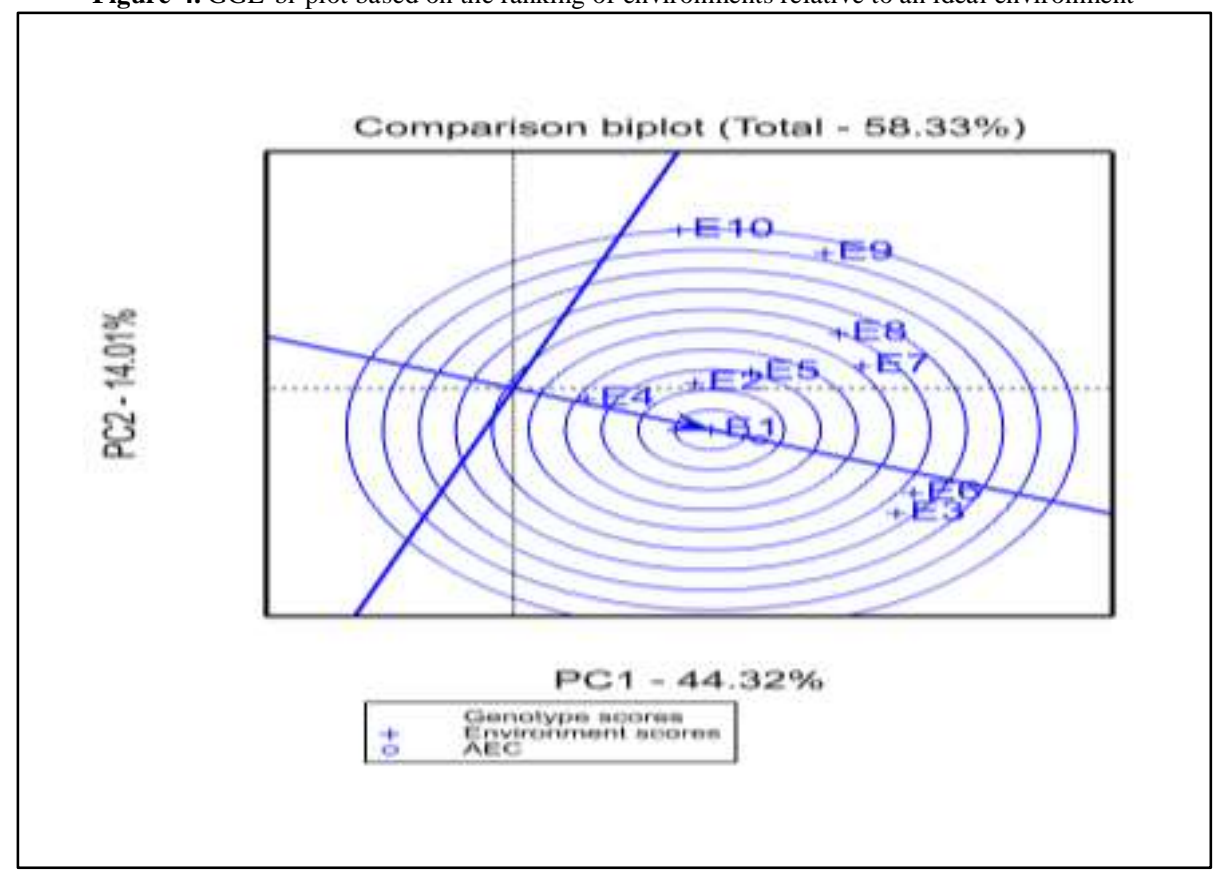

E1=Humera-1, E2=Humera-2, E3=Dansha-1, E4=Dansha-2, E5=Sheraro-1, E6=Sheraro-2, E7=Wargiba1, E8=Wargiba-2, E9=Maykadra, E10=Gendawuha

The mean oil content of genotypes were inconsistent across locations due to environmental factors. G12 was ideal genotype for oil content and G14, G16, G7, G2 and G5 were stable, while G3 had high oil content and unstable. E10 was the ideal environment followed by E4 and E9 and the most stable for oil content. On the other hand, E2, E6 and E8 were plotted far from the ideal environment considered as unstable and unfavorable environments (Figure 5). 
Figure-5. GGE-biplot based on the ranking of environments and genotypes for oil content relative to an ideal environment and ideal genotype.

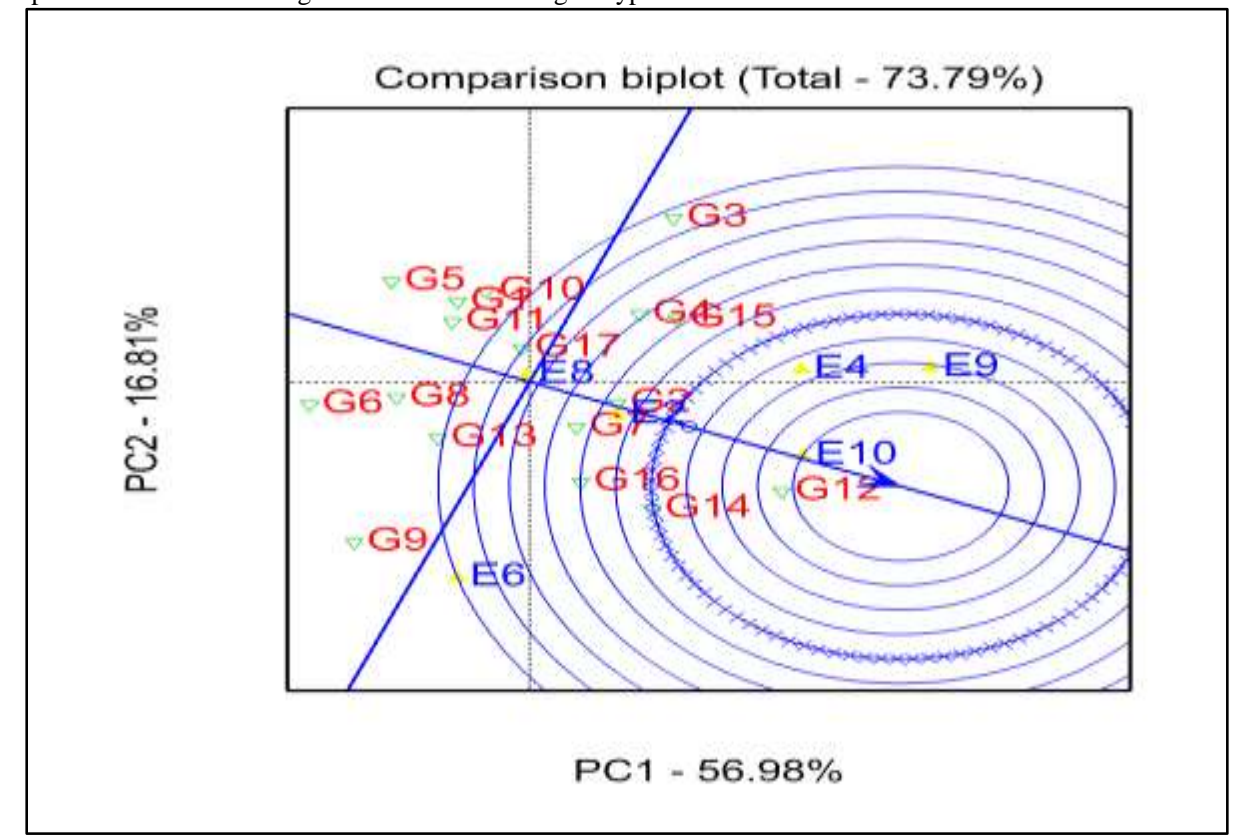

E2=humera-2, E4=Dansha-2, E6=Sheraro-2, E8=Wargiba-2, E9=Maykadra, E10=Gendawuha. G1= HuRC 4, G2= ACC202514, G3 = Land race Gumero, G4= Abuseffa, G5= HuRC-1, G6= Rawyan -2 , G7= HuRC 3, G8= Acc 202300, G9= Kefif, G10= Acc111824, G11= Acc 111518, G12= Acc 27913, G13= Gumero, G14= HuRC-2, G15= Acc 227880, G16= Setit -1, G17 = Hirhir. Environments: E1=Humera-1, E2=Humera-2, E3=Dansha-1, E4=Dansha-2, E5=Sheraro-1, E6=Sheraro-2, E7=Wargiba-1, E8=Wargiba-2, E9=Maykadra, E10=Gendawuha

\section{3. 'Which-Won-Where' Pattern and Mega-environment Identification}

The ten environments fell into six sectors with different winner genotypes and the bi-plot showed that four vertex genotypes, G4, G15, G1 and G8. From winner genotypes except G8 were high yielding in favorable environments. The GGE biplot identified two different sesame growing mega-environments. The first megaenvironment containing overlapping environments with highest yielding environment (E3) in Dansha area with a vertex genotype G4 and the higher yielding environment (E6) in Sheraro area with winner genotype G3; and second environment includes medium E1 and E10 to low yielding E2, E4, E5, E7, E8 and E9 environments, respectively with the winner genotype G1 (Figure 5).

Figure-6. Which-Won-Where View of GGE bi-plot genotypes and environments of yield

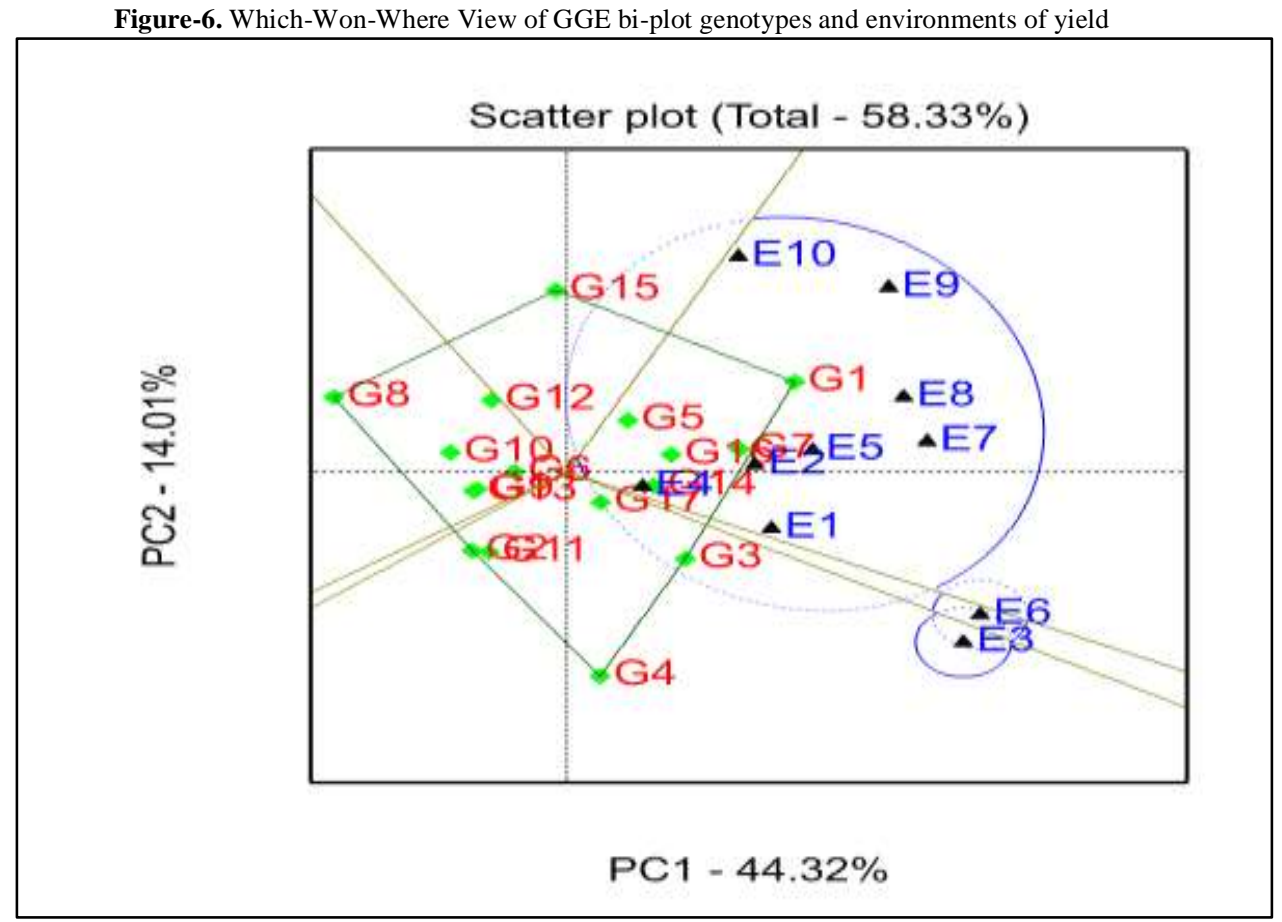

G1 = HuRC-4, G2= ACC202514, G3= Land race Gumero, G4= Abuseffa, G5= HuRC-1, G6= Rawyan -2, G7= HuRC-3, G8= Acc 202300, G9= Kefif, G10= Acc111824, G11= Acc 111518, G12= Acc 27913, G13= Gumero, G14= HuRC-2, G15= Acc 227880, G16= Setit -1, G17 = Hirhir. E1=Humera-1, E2=Humera-2, E3=Dansha-1, E4=Dansha-2, E5=Sheraro-1, E6=Sheraro-2, E7=Wargiba-1, E8=Wargiba-2, E9=Maykadra, E10=Gendawuha 
According the GGE bi-plot six sections with five vertex genotypes G3, G5, G6, G12 and G9 and identified three different sesame growing mega-environments for oil content: The first environment containing G12, G7 and G2 in the mega-environment group of E2 (Humera-2), E4 (Dansha) and E10 (Gendawuha). The second environment E6 (Sheraro-2) containing G9 and third environment E8 (Wargiba), containing G17 presented in (Figure 7).

Figure-7. The environment-vector view of the GGE bi-plot to show similarities of oil content

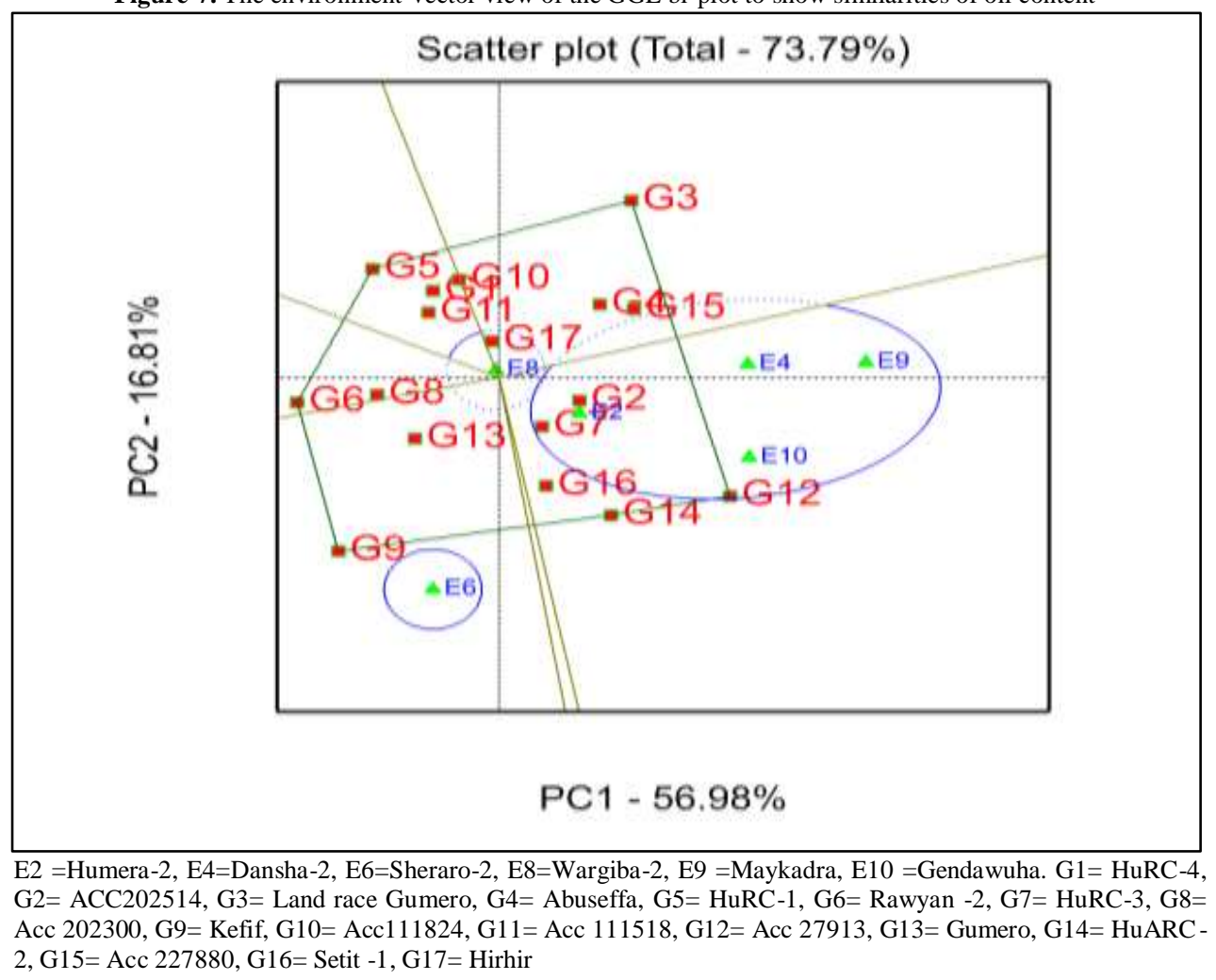

\section{Summaryand Conclusion}

According to the GGE bi-plot different sesame growing environments grouped into two for yield production: The first environment containing the favorable environment Dansha area with a vertex G4 and Sheraro area with winner G3; and second environment includes medium to low environments E2 (Humera-2), E4 (Dansha-2), E5 (Sheraro-1), E7 (Wargiba-1), E8 (Wargiba-2) and E9 (Maykadra). GGE bi-plot classified three different sesame growing mega-environments for oil content production: The $1^{\text {st }}$ environment containing G12, G7 and G2 in the mega-environment group of Humera, Dansha and Gendawuha. The $2^{\text {nd }}$ environment, Sheraro containing G9 and the $3^{\text {rd }}$ environment Wargiba contained G17. AMMI model and GGE bi-plot were better for partitioning the GEI into the causes of variation. G1, G7, and G3 were high yielder and the most stable both in terms of seed yield and oil content. Moreover, showed yield advantage over the standard and local check. Hence, G1, G7 and G3 were recommended for wider environments and G14 and G4 for favorable environments Sheraro and Dansha, respectively.

\section{Acknowledgment}

I would like to acknowledge to Humera Agricultural Research Center (HuARC), Gonder Agricultural Research Center (GARC), Shire-Mytsebri Agricultural Research Center (SMARC) and Alamata Agriculture Research Center (AARC) crop members and research staff for helping me entire the study. To Sesame Business Network (SBN) and Tigray Agricultural Research Center (TARI).

\section{References}

[1] Janick, J. and Whipkey, A., 2002. Trends in new crops and new uses. Alexandria: ASHS Press.

[2] Gauch, H. G., 1988. "Model selection and validation for yield trials with interaction." Biometrics, vol. 44, pp. 705-715.

[3] Zobel, R. W., Wright, M. J., and G., G. H., 1988. "Statistical analysis of a yield trial." Agronomy Journal, vol. 80, pp. 388-39.

[4] Purchase, J. L., 1997. Parametric analysis to describe GEI interaction and yield stability in winter wheat. PhD Dissertation. Department of Agronomy, Faculty of Agriculture, University of the Free State, Bloemfontein, South Africa, p. 148.

[5] Farshadfar, E., Vaisi, Z., and Yaghotipoor, A., 2011. "Non parametric estimation of phenotypic stability in Wheat-barley disomic addition lines." Annals of Biological Research, vol. 2, pp. 586-598.

[6] Steel, R. and Torrie, J., 1998. Principles and procedures of statistics a biometrical approach. 2nd ed. Mc Graw-Hill, Inc, pp. 471-472. 
[7] Yan, W. and Rajcan, I., 2000. "Biplot analysis of test sites and trait relations of soybean in Ontario." Crop Science, vol. 42, pp. 11-20.

[8] Yan, W. and Kang, M. S., 2003. "GGE biplot analysis: a graphical tool for breeders." In M. S. Kang (ed.), Geneticists, and Agronomist. Boca Raton, FL: CRC Press. pp. 63-88.

[9] Sabaghnia, N., Karimizadeh, R., and Mohammadi, M., 2013. "GGL bi-plot analysis of durum wheat (Triticum turgidum spph durum) yield in multi-environment trials." Bulgarian Journal of Agricultural Science, vol. 19, pp. 756-765.

[10] Farshadfar, E., Rashidi, M., Mahdi, J. M., and Zali, H., 2013. "GGE bi-plot analysis of genotype $\times$ environment interaction in chickpea genotypes." European Journal of Experimental Biology, vol. 3, pp. 417-423.

[11] Munawar, M., Hammad, G., and Shahbaz, M., 2013. "Evaluation of maize (zea mays 1.) hybrids under different environments by gge bi-plot analysis." American-Eurasian Journal of Agriculture and Environmental Science, vol. 13, pp. 1252-1257.

[12] Fiseha, B., Yemane, T., and Fetien, A., 2015. "AMMI analysis of Genotype x Environment interaction and stability analysis of sesame genotypes in northern Ethiopia." Asian Journal of Plant Science, vol. 13, pp. 178-183.

[13] Untung, S., Wage, R. R., Sarah, B. J., and Ali, J., 2015. "GGE biplot analysis for Genotype X Environment Interaction on yield trait of high $\mathrm{Fe}$ content rice genotypes in Indonesian irrigated environments." AGRIVITA, vol. 3, pp. 265-275.

[14] Farshadfar, E., Mohammadi, R., Aghaee, M., and Vaisi, Z., 2012. "GGE biplot analysis of genotype x environment interaction in wheat-barley disomic addition lines." Aust. J. Crop Sci., vol. 6, pp. 1074-1079.

[15] Mitrovic, B., Stanisavljevi, D., Treski, S., Stojakovic, M., Ivanovic, M., Bekavac, G., and Rajkovic, M., 2012. "Evaluation of experimental Maize hybrids tested in Multi-location trials using AMMI and GGE biplot analysis." Turkish Journal of Field Crops, vol. 17, pp. 35-40.

[16] Kaya, Y., Akcura, M., and Taner, S., 2006. "Gge-biplot analysis of multi-environment yield trials in bread wheat." Turk Journal Agriculture, vol. 30, pp. 325-337.

[17] Bereket. and Yirgalem, 2012. "Ethiopia meteorology agency, tigray branch. Report on soil and metrological data for dansha, humera, and maykadra."

[18] IPMS-ETHIOPIA, 2005. "Improved productivity market success description of metema district." Pilot Survey, p. 7.

[19] Humera Agricultural Research Center, 2018. "Annual report, Tigray, Ethiopia."

[20] GenStat, 2009. Gen stat for windows. 16th ed. Introduction. VSN International, Hemel Hempstead.

[21] Mekonnen, M., Firew, M., and Adugna, W., 2015. "Gei interaction of sesame (sesamum indicum 1.) in eastern amhara region." Ethiopia. African Journal of Agricultural Research, vol. 10, pp. 2226-2239.

[22] Mohammed, A., 2015. "Genotype x environment analysis for seed yield and its components in sesame (sesamum indicum 1.) evaluated across diverse agro-ecologies of the awash valleys in Ethiopia." Journal of Advanced Studies in Agricultural, Biological and Environmental Sciences, vol. 4, pp. 1-14.

[23] Zenebe, M. and Hussien, M., 2010. "Study on genotype x environment interaction of oil content in sesame (sesamum indicum 1.)." World Journal of Fungal and Plant Biology, vol. 1, pp. 15-20.

[24] Alege, O. A. and Musapha, O. T., 2013. "Assessment of Genetic diversity in Nigerian Sesame using proximate analysis." Global journal of Bio-science and Biotechnology, vol. 2, pp. 57-62.

[25] Yahaya, S. A., Falusi, O. A., Daudu, O. A. Y., Muhammad, L. M., and Abdulkarim, B. M., 2010. "Evaluation of seed-oil and yield parameters of some Nigerian sesame (Sesamum indicum L.) Accessions." International Journal of Agriculture and Crop Sciences, pp. 661-664. Available: https://www.researchgate.net/publication/322098145_Evaluation_of_seedoil_and_yield_parameters_of_some_Nigerian_sesame_sesamum_indicumlinn_Accessions

[26] Eberhart, S. A. and Russell, W. A., 1966. "Stability parameters for comparing varieties." Crop Science, vol. 6, pp. 36-40.

[27] Lin, C. S. and Binns, M. S., 1988. "A superiority measure of cultivar performance for cultivar x location data." Canadian Journal of Plant Science, vol. 68, pp. 193-198.

[28] Wricke, G., 1962. "Über eine method zur erfassung der ökologischen streuberite in feldversuchen. Z." Pflanzenzüchtg, vol. 47, pp. 92-96.

[29] Mohammed, A., Firew, M., Amsalu, A., and Mandefro, N., 2015. "Genotype x nenvironment and stability analysis of oil content in sesame (sesamum indicum 1.) evaluated across diverse agro-ecologies of the awash valleys in Ethiopia." American Journal of Experimental Agriculture, vol. 9, pp. 1-12.

[30] Asnake, W., Henry, M., Temesgen, Z., and Girma, T., 2013. "Additive main effects and multiplicative interactions model (AMMI) and genotype main effect and genotype by environment."

[31] Naroui, R. M. R., Abdul, K., M. Y. M., Rafii, H., M. R., Jaafar, N., and Farzaneh, A., 2013. "Genotype × environment interaction by AMMI and GGE biplot analysis in three consecutive generations of wheat (Triticum aestivum) under normal and drought stress conditions." Australia Journal of Crop Science, vol. 7, pp. 956-961.

[32] Yan, W., Kang, M. S., Ma, B., Woods, S., and Cornelius, P. L., 2007. "GGE Biplot vs. AMMI analysis of genotype by environment data." Crop Science, vol. 47, pp. 643-655. 